\title{
EFFECTS OF ACUTE AND LONG-TERM CANNABIS TREATMENT ON RESTRAINT-INDUCED GASTRIC ULCERATION IN RATS
}

\author{
Helenice DE SOUZA, Eleonora TRAJANO, Fernando Varela de CARVALHO \\ and João PALERMO NETO \\ Laboratory of Therapetitics, Faculty of Veterinary Medicine, \\ University of São Paulo, São Paulo, Brasil
}

Accepted March 1, 1978

We designed the present experiments in order to investigate the effects of Cannabis sativa extract (CE) treatment upon restraint induced gastric ulceration in rats. The major intent of the present study was to determine the possible relationships among the schedule of $\mathrm{CE}$ administration, dose of $\mathrm{CE}$ administered and immobilization-induced gastric lesions.

Wistar rats of both sexes and genetically similar were housed and later tested in a quiet room with a controlled temperature $\left(19-23^{\circ} \mathrm{C}\right)$ on a non-reversed 12-hr-night-cycle, with light onset at $07: 30 \mathrm{hr}$. Subjects were 80 days old at the beginning of the experiments and were provided food and water "ad libitum" until the moment of immobilization. CE extract was obtained, prepared and suspended in $0.9 \%$ saline plus Tween- 80 as previously described (1). The control solutions consisted both of $0.9 \%$ saline plus Tween-80 (CS) and $0.9 \%$ saline (S). The biological activity of the extract, measured by the corneal areflexia method in rabbits (Gayer's test), according to Santos et al. (2) was $0.54 \mathrm{mg} / \mathrm{kg} \cdot 0.004$. All drugs were administered i.p. in an equal volume of $1.0 \mathrm{ml} / \mathrm{kg}$.

The experiments were performed in ten replications. For the acute experiments subjects were randomly divided into 7 groups, removed from their home cages in fixed numerical order and injected both $24 \mathrm{hr}$ and immediately before immobilization respectively with $5.0,10.0,20.0,40.0$ and $60.0 \mathrm{mg} / \mathrm{kg}$ of $\mathrm{CE}$ or an equal volume of $1.0 \mathrm{ml} / \mathrm{kg}$, of CS or S. In the long-term treatments the animals were given 40 and $60 \mathrm{mg} / \mathrm{kg}$ of CE or an equal volume of $1.0 \mathrm{ml} / \mathrm{kg}$ of CS or $\mathrm{S}$ for 20 days and were immobilized immediately after the last administration. Some animals were also treated for 25 days with $60.0 \mathrm{mg} / \mathrm{kg}$ of CE or $1.0 \mathrm{ml} / \mathrm{kg}$ of CS and sacrificed $24 \mathrm{hr}$ after the last injection, without restraint, for stomach observation. Immobilization was performed using the standard method described in detail elsewhere (3). At the end of the restraint period the rats were anesthetized with ether, decapitated and the stomachs immediately removed, cut open along the greater curvature, washed in $0.9 \%$ saline and examined for lesions. To minimize possible effects of circadian hormonal changes that could interfere with the results $(4,5)$, the experiments wete designed in order to allow all subjects to be restrained and/or sacrificed at the same time of the day, i.e., at noon. The degree of ulceration was evaluated by the method described by Pauls et al (6). Briefly, the stomachs free of ulcers were called "clear" or "zero" and those with the most ulceration "four plus", according to the quantity of ulcers they showed. The percentage 
TABLE 1. Effects of acute and long-term cannabis extract (CE) treatment upon restraint-induced ulceration in rats

\begin{tabular}{|c|c|c|c|c|c|c|}
\hline Condition & $\begin{array}{l}\text { Schedule of } \\
\text { administration }\end{array}$ & Treatment & $\begin{array}{c}\text { Dose } \\
(\mathrm{mg} / \mathrm{kg})\end{array}$ & $n$ & $\begin{array}{l}\text { Average } \\
\text { degree of } \\
\text { ulceration }\end{array}$ & $\begin{array}{l}\% \text { of rats } \\
\text { with } \\
\text { ulcers }\end{array}$ \\
\hline \multirow{11}{*}{ Restrained } & \multirow{7}{*}{ acute } & $\mathrm{NaCl} 0.9 \%$ & - & 29 & 1,79 & 82.76 \\
\hline & & $\begin{array}{l}\mathrm{NaCl} 0.9 \% \\
-+ \text { Tween- } 80\end{array}$ & - & 32 & 1,84 & 65.63 \\
\hline & & $\mathrm{CE}$ & 5.0 & 18 & 1,78 & 77.78 \\
\hline & & CE & 10.0 & 19 & 2,44 & 75.00 \\
\hline & & $\mathrm{CE}$ & 20.0 & 24 & 2,35 & 78.26 \\
\hline & & $\mathrm{CE}$ & 40.0 & 16 & 1,00 & $50.00^{*}$ \\
\hline & & $\mathrm{CE}$ & 60.0 & 12 & 0,50 & $41.67^{* *}$ \\
\hline & \multirow{4}{*}{$\begin{array}{l}\text { long-term } \\
\text { (20 days) }\end{array}$} & $\mathrm{NaCl} 0.9 \%$ & - & 17 & 2,94 & 100.00 \\
\hline & & $\begin{array}{l}\mathrm{NaCl} 0.9 \% \\
+ \text { - Tween- } 80\end{array}$ & - & 15 & 3,00 & 100.00 \\
\hline & & $\mathrm{CE}$ & 40.0 & 8 & 3,63 & 100.04 \\
\hline & & $\mathrm{CE}$ & 60.0 & 19 & 3,32 & 94.74 \\
\hline \multirow{2}{*}{ Unrestrained } & \multirow[t]{2}{*}{$\begin{array}{l}\text { long-term } \\
\text { (25 days) }\end{array}$} & $\begin{array}{l}\mathrm{NaCl} 0.9 \% \\
+ \text { Tween-80 }\end{array}$ & 一 & 10 & 0,40 & $20.0 \%$ \\
\hline & & $\mathrm{CE}$ & 60.0 & 10 & 2,10 & $80.00^{* * *}$ \\
\hline
\end{tabular}

$\mathrm{n}=$ number of rats. ${ }^{*}=\mathrm{p}<0.05$ and ${ }^{* *}=\mathrm{p}<0.01$ in relation to animals acutely treated with $\mathrm{NaCl} 0.9 \%$ (S). ${ }^{* * *}=\mathrm{p}<0.01$ in relation to unrestrained animals treated for 25 days with $\mathrm{NaCl} 0.9 \%+\frac{1}{1}$ ween-80(CS)

of animals showing ulcers in each group was also determined and the median dose (AD50), $95 \%$ confidence limits and slope of the dose-response curve were calculated (7). (Chi) ${ }^{2}$ test was also used, and the probability of $p<0.05$ was considered to indicate a significant difference for all comparisons made.

Immobilization induced haemorrhagic ulcers, associated with numerous petechiae only in the glandular segment of the gastric mucosa. As shown in Table 1, the incidence of ulceration was not significantly different in $\mathrm{CS}$ and $\mathrm{S}$ treated rats both in acute and longterm experiments. Nevertheless both the number of ulcers and the average degree of ulceration were higher in long-term treated animals. Concerning the effects of acute $\mathrm{CE}$ treatment, the doses of 40 and $60 \mathrm{mg} / \mathrm{kg}$ significantly affected the lesion pattern and incidence ( $p<0.05$ and $p<0.01$ respectively). Subjects of these groups showed a low lesion incidence in the form of occasional petechiae. Based on our data, the protective AD50 for acute $\mathrm{CE}$ treatment was $40 \mathrm{mg} / \mathrm{kg}(19.20-83.68)$ being the slope of the dose-response curve 0.114 (0.112-0.115).

Data obtained with long-term CE treatment show that 20 daily injections with doses of 40 and $60 \mathrm{mg} / \mathrm{kg}$ provided no protection. As a matter of fact, the reverse was observed since the stomachs of five and nine animals long-term treated respectively with 40 and $60 \mathrm{mg}$; $\mathrm{kg}$ of $\mathrm{CE}$ had a total of 58 ulcers. The remaining animals of these two groups had 2 or 3 lesions each, the ulcers being circular in shape and slightly less than $1 \mathrm{~cm}$ in length.

Table 1 also shows that the percentage of rats with ulcers was significantly higher 
$(p<0.01)$ in unrestrained animals treated for 25 days with $60 \mathrm{mg} / \mathrm{kg}$ of $\mathrm{CE}$. The stomachs of these animals were transparent rather than opague, thinner than normal and showed diffuse erythema, gastritis, and prominent ruggae. Moreover, recently ingested food and mucosal lining were virtually absent. In contrast, the stomachs of all 10 control animals, long-term treated with CS and sacrificed without restraint were filled with food, and the mucosa were entirely normal except for some lesions with a diameter of $3 \mathrm{~mm}$ or less in two of these rats.

Both cannabinoids and belladonna alkaloids produce dry mouth (8) in addition bradycardia produced by vagal stimulation in the anesthetized dog may be attenuated by cannabinoids $(9,10)$; finally $1^{9}$-THC, a constituent of CE (11), inhibited Ach-induced contraction of the vas deferens (12). These findings may be considered to support the notion that the protective effect of acute CE treatment on immobilization-induced gastric lesions was a consequence of its effect at muscarinic sites. Nevertheless, such speculation is not feasible since it has been reported that acute administration of CE, $A^{9}$-THC and its isomers and derivatives induce, in laboratory animals, many effects similar to those produced by chlorpromazine and reserpine (13), and it is known that tranquilizers also prevent the development of stress ulcers (14). In the meantime, our results show that long-tern CE treatment induced gastric lesions in unrestrained animals. The stress of being given daily injections also may be important in ulcer production since the percentage of rats with ulcers were higher in all long-term treated animals. In a previous work, we observed that iongterm CE treatment caused not only a significant increase in plasma corticosterone but also in both wet pituitary and paired adrenal weights (15). Since $0^{0}$-THC also produces strong pituitary-adrenocortical activation (16) it is reasonable to assume that the animals submitted to the long-term treatment in our experiments were under conditions of severe stress. Another possible explanation could be the development of tolerance to the protective effects of CE, which has already been observed by different authors in different behavioral tests (13).

\section{REFERENCES}

1) CARLINi, E.A. AND KRAMer, C.: Effects of Camabis sativa (marihuana) on maze performance of the rat. Psychopharmacologia, Berl. 7, 175-181 (1965); 2) Santos, M., Sampaio, M.R.P., FERNANDES, N.S. AND CARLINI, E.A.: Effects of Camabis satira (marihuana) on fighting beharior of mice. Psychopharmacologia, Berl. 8, 437-447 (1966); 3) BRodle, D.A. AND HANson, H.M.: A study of the factors involved in the production of gastric ulcers by the restraint technique. Gastroenterology 38, 353-360 (1960): 4) ADER, R.: Gastric erosions in the rat: effects of immobilization at different points in the activity cycle. Science 145, 406-407 (1964); 5) DIXIT, B. BuCKLEY, J.P.: Circadian changes in brain 5-hydroxytryptamine and plasma corticosterone in the rat. Life Sci. 6, 755-758 (1967); 6) Pauls, F., Wick, A.N. ANd Mackay, E.M.: An assay method for anti-ulcer substances. Gastroenterology 8, 774-782 (1947); 7) LiTCHFiELD, J. T.. JR. AND Wilcoxon, F.: A simplified method of evaluating dose-effect experiments. J. Pharmacol. exp. Ther. 96, 99-113 (1949); 8) JoHnson, S. AND Domino, E.F.: Some cardiovascular effects of marihuana smoking in normal volunteers. Clin. Pharmacol. Ther. 12, 762-768 (1971): 9) Kubeva, R.K., Cavero, I., Jandhyala, B.S. and Buckley, J.P.: Certail respiratory and cardiovascular effects of $J^{9}$-THC in dogs. Pharmacologist 13, 311 (1971); 10) Cavero. I., BUCKLEY, J.P. AND JANDHYALA, B.S. : Parasympatholytic activity of $(-)\lrcorner^{9}$-trans-tetrahydrocannabinol in mongrel dogs. Europ. J. Pharmacol, 19, $301-304$ (1972); 11) Mechoulam. R.: Marihuana chemistry. Science 168, 1159-1166 (1970); 12) GASCON, A.L. ANd Pérès, M.T.: 
Elreet of $J^{9}$ - and $d^{8}$-tetrahydrocannabinol on the peripheral autonomic nervous system in vitro. Canad. J. Physiol. Pharmacol. 51, 12-21 (1973); 13) CARlini, E.A.: Acute and chronic behavioral effects of Cannabis sativa. Proc. 5th int. Congr. Pharmacology, Vol. 1, p. 31, San Francisco, U.S.A. (1972); 14) Takagi, K. Kaslya, Y. And Watanabe, K.: Studies on the drugs for peptic ulcer. A reliable method for producing stress ulcer in rats. Chem. Pharm. Bull., Tokyo 12, 465 (1964); 15) Palfrmo Neto, J., Nunes, J.F. And Carvalho, F.V.: The effects of chronic cannabis treatment upon brain 5-hydroxytryptamine, plasma corticosterone and aggressive behavior in female rats with different hormonal status. Psychopharmacologia, Berl. 42, 195-200 (1975); 16) Kubena, R.K., Perhach, J., Jr. and Barry, H., III.: Corticosterone elevation mediated centrally by $\Delta^{1}$-tetrahydrocannabinol in rats. Europ. J. Pharmacol. 14, 89-92 (1971) 